\title{
RelA-Associated Inhibitor
}

National Cancer Institute

\section{Source}

National Cancer Institute. RelA-Associated Inhibitor. NCI Thesaurus. Code C95030.

RelA-associated inhibitor ( $828 \mathrm{aa}, \sim 89 \mathrm{kDa}$ ) is encoded by the human PPP1R13L gene.

This protein is involved in the modulation of cellular tumor antigen p53-mediated apoptosis and NF-kappa B-mediated gene expression. 